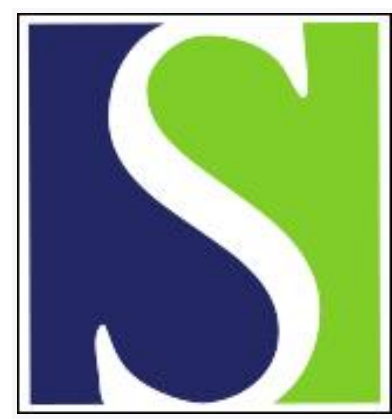

Scand J Work Environ Health 2010;36(4):289-298

https://doi.org/10.5271/sjweh.3018

Published online: 04 Jun 2010, Issue date: 01 Jun 2010

A review of case studies evaluating economic incentives to promote occupational safety and health

by Elsler D, Treutlein D, Rydlewska I, Frusteri L, Krüger H, Veerman T, Eeckelaert L, Roskams N, Van Den Broek K, Taylor TN

Affiliation: European Agency for Safety and Health at Work, Gran Vía 33, E-48009 Bilbao, Spain. elsler@osha.europa.eu

Refers to the following texts of the Journal: 2009;35(6):403-413

2007;33(2):85-95

The following articles refer to this text: 2010;36(4):269-271;

2018;44(5):458-474

Key terms: case study; cost-benefit analysis; economic incentive; economics; evaluation; external economic incentive; occupational health and safety; occupational safety and health; $\mathrm{OSH}$; promotion; review

This article in PubMed: www.ncbi.nlm.nih.gov/pubmed/20523960 


\title{
A review of case studies evaluating economic incentives to promote occupational safety and health
}

\author{
by Dietmar Elsler, PhD, ${ }^{1}$ Daniela Treutlein, PhD, ${ }^{2}$ Iza Rydlewska, PhD, ${ }^{3}$ Liliana Frusteri, PhD, ${ }^{4}$ Henning \\ Krüger, MBA, ${ }^{5}$ Theo Veerman, MSc, ${ }^{6}$ Lieven Eeckelaert, MSc, ${ }^{7}$ Nele Roskams, MA, ${ }^{7}$ Karla Van Den Broek, \\ MA, ${ }^{7}$ Terry N Taylor, MSc ${ }^{1}$
}

Elsler D, Treutlein D, Rydlewska I, Frusteri L, Krüger H, Veerman T, Eeckelaert L, Roskams N, Van Den Broek K, Taylor TN. A review of case studies evaluating economic incentives to promote occupational safety and health. Scand $J$ Work Environ Health. 2010;36(4):289-298.

Objectives In many European countries, external economic incentives are discussed as a policy instrument to
promote occupational safety and health (OSH) in enterprises. This narrative case study review aims to support
policy-makers in organizations providing such incentives by supplying information about different incentive
schemes and their main characteristics such as effectiveness, efficiency, and feasibility.

Methods The focal point and topic centre network of the European Agency for Safety and Health at Work were used to collect case studies about incentive schemes aimed at supporting the prevention of occupational accidents and diseases in enterprises. Such incentives are rarely described in the scientific literature. To be considered for this review, studies had to focus on external financial benefits that could be provided as part of an insurancerelated incentive or a governmental subsidy scheme.

Results In total, 14 cases were included in the review: 6 insurance premium- and 8 subsidy-based schemes. Of these, 13 contained an evaluation of the incentive scheme, of which 7 use quantitative criteria. Three cases provided sufficient data to conduct a cost-benefit analysis. Most qualitative evaluations related to the successful management of the program and the effectiveness of the promoted measures in the workplace. Regarding the latter, quantitative criteria covered accident rates, sick leave, and general improvement in working conditions. The cost-benefit analyses all resulted in a positive payout ratio, ranging from $€ 1.01-4.81$ return for every $€ 1$ invested.

Conclusions Generally, we found economic incentive schemes to be feasible and reasonably effective. However, analysis regarding the efficiency of such schemes is scarce and our evaluation of the cost-benefit analysis had to rely on few cases that, nevertheless, delivered positive results for large samples. Besides this finding, our study also revealed deficits in the quality of evaluations. In order to enable policy-makers to make well-informed decisions about public investments in $\mathrm{OSH}$, better standards for reporting and evaluating incentive schemes are needed.

Key terms economics; external economic incentive; cost-benefit analysis; occupational health and safety; OSH.

The need for a greater understanding of the effectiveness of economic incentives to promote occupational safety and health (OSH) is mirrored in the new European OSH strategy (1), especially with regard to small and medium-sized enterprises. There is also a need for guidance of organizations that provide economic OSH incentives (eg, many insurers would like to put in place better incentive schemes, but they know neither how to do it nor which models have proven effective and efficient). Therefore, this article reviews the contents of 14 incentive schemes, used in 8 European countries, which apply defined evaluation criteria. It focuses on insurance premium variations and subsidy programs. In addition to this review, a cost-benefit analysis was calculated for 3 case studies, comparing their efficiency on the societal level.

1 European Agency for Safety and Health at Work (EU-OSHA), Bilbao, Spain.

2 TNO, Hoofddorp, the Netherlands.

3 Nofer Insitute, Lodz, Poland.

4 Italian Workers' Compensation Authority (INAIL), Rome, Italy.

5 Fleischerei Berufsgenossenschaft (FBG), Mainz, Germany.

6 AStri Research and Consultancy Group, Leiden, the Netherlands.

7 Prevent, Brussels, Belgium. 
So far in the scientific literature, reviews about the effectiveness of "experience rating" (ie, pricing premiums for different groups or individuals based on the group or individual's history of claims) have found at least moderate evidence (2-4) of a decrease in the number of work accident insurance claims. In Germany, the accident premium variations have a long tradition as they were made possible by the accident insurance law in 1884 . Nowadays, accident insurers are legally obliged to offer a premium differentiation (5). According to several authors (6-8), the German accident insurers' bonus-malus system has certainly had a positive effect, since the accident rates have decreased considerably over the last decades.

Overall, the scientific literature provides some evidence for the positive effects of experience rating, but also points to potential shortcomings connected with this type of economic incentive instrument. According to the European Foundation for the Improvement of Living and Working Conditions (9), for instance, the accident rate in individual enterprises can be significantly affected by statistical fluctuations, particularly in the case of small- and medium-sized enterprises. Statistical "good luck" can also mask serious lapses in health and safety practice or negligible health and safety prevention. Economic incentives based on accident rates alone may thus penalize high claims arising from purely random events (in situations where either the occurrence of an event or its severity is related to a random occurrence and not poor risk-minimization strategy at the enterprise) and reward the "careless but lucky". In taking the past as a proxy for current and future risk, these incentives do not address the effectiveness of current preventive behavior. Ideally, premium assessment and reward should be based on future risk. This could be achieved by incentive schemes that reward specific prevention behavior such as investment in safer machinery and equipment or the introduction of an OSH management system.

Despite the above discussion about the advantages and drawbacks of experience rating, the report of the European Foundation (9) also highlights the scope for increasing the use of economic instruments in almost all EU countries. The report stresses the need for further development of economic incentive schemes that are based on present risk factors and reward specific prevention activities. Although insurance-based incentives seem to be most popular in Europe (10), such prevention activities could be equally stimulated by governmental subsidy schemes if incentives are difficult to implement in certain national workers' compensations systems. An expert survey of the European Agency for Safety and Health at Work (EU-OSHA) (10) came to the conclusion that many member states could benefit from the introduction of adapted economic incentive schemes in order to motivate companies towards more prevention efforts. In their rating of incentive measures, the experts assessed insurance premium variations as most suitable for their country $(71 \%)$, followed by OSH promotion $(55 \%)$, tax reduction (49\%), and awards (49\%).

\section{Methods}

This research was carried out as part of an EU-OSHA project on economic incentives. The detailed descriptions of the included case studies are available in an EU-OSHA prevention report (11). As research literature regarding economic incentive schemes in Europe is scarce, the Agency decided to use the its Topic Centre (TC-OSH) and network of national focal points to collect the case study information. The questionnaire for the case study collection was drafted in cooperation with TC-OSH (a consortium of leading European OSH research institutes) and included questions concerning the legal and political background in various countries (11). The questionnaire was sent out to the network of EU-OSHA focal points, which consists of national contact institutions nominated by the 27 Member States. The focal points are usually located in the responsible OSH ministry (eg, Ministry of Employment) or national research institute. Eight questionnaires were received, namely from Austria, the Czech Republic, Denmark, Finland, Lithuania, Poland, Slovakia, and the United Kingdom. Further case studies from other countries were provided by the TC-OSH experts or competent contact persons in the other countries. All case studies were written up in a consistent structure provided by EU-OSHA and integrated in the Agency project report on economic incentives. In addition, as a result of an EUOSHA expert group workshop, two more case studies were included in the analysis.

This study aims to provide a review of case studies that demonstrate good practice examples undertaken in several European countries to motivate firms to promote OSH prevention measures by means of economic incentives. "Prevention measures" are defined in a broad sense, including the prevention of work-related accidents and mental as well as physical diseases. The focus of our study was on firm-extern financial benefits (ie, incentives provided by external organizations) such as insurance companies or governmental bodies. According to our definition, we did not focus on a particular outcome variable but included all studies dealing with prevention measures in a broader sense.

In order to be included in this review, the case studies had to meet certain criteria. The described incentive scheme had to be an external financial stimulus or at least had to provide a service of a certain economic value, such as a consultancy service. For the purpose of this review, evaluation criteria (eg, the size of the incentive, the budget of the program, the feasibility 
and the effectiveness of the scheme) were defined and systematically extracted from the case studies (tables 1 and 2). Even if all this information could not be provided to a full extent, cases were included for reasons of geographical coverage in order to draw a full picture of the variety of European incentive schemes. Recognition schemes or tools simply used to calculate economic OSH benefits were not included in this analysis. For this reason, four case studies collected by the EU-OSHA network have been omitted from this review but are briefly described in the EU-OSHA report as "snapshots" (11).

In total, the survey among the EU-OSHA network and expert group yielded 18 case studies. Of those, 14 case studies from 8 European countries were included in this review according to the criteria mentioned above. The case studies were divided into those covering insurance premium-based incentive schemes all provided by insurance companies $(\mathrm{N}=6)$, and those covering subsidy-based incentive schemes mainly provided by governmental institutions $(\mathrm{N}=8)$.

\section{Cost-benefit calculations}

To be included in the cost-benefit calculations, the case studies had to provide exact data on the costs of the incentive program. Further, it was necessary that the quantitative benefit was either estimated as reduced accident numbers or lower sick leave rates. Only 3 of

Table 1. Insurance premium-related incentive schemes. [SME=small- and medium-sized enterprise]

\begin{tabular}{|c|c|c|c|c|c|c|}
\hline Organization & Type of incentive & $\begin{array}{l}\text { Insurance premium } \\
\text { or incentive }\end{array}$ & Bonus & Malus & Evaluation & Target group \\
\hline $\begin{array}{l}\text { Fleischerei } \\
\text { Berufsgenossen- } \\
\text { schaft (FBG), } \\
\text { German social } \\
\text { accident insurance } \\
\text { institution for the } \\
\text { meat-processing } \\
\text { industry }\end{array}$ & $\begin{array}{l}\text { Experience rating } \\
\text { depending on accident } \\
\text { rates and stimulation of } \\
\text { specific prevention } \\
\text { activities through } \\
\text { premiums }\end{array}$ & $\begin{array}{l}€ 292.12 \text { (annual } \\
\text { insurance premium } \\
\text { related to average } \\
\text { income); } \leq € 14.06 \\
\text { for average income } \\
\text { ( } 5 \% \text { of premium); } \\
€ 5.5 \text { per worker per } \\
\text { year for incentives }\end{array}$ & $\begin{array}{l}\leq 20 \% \text { re- } \\
\text { bate, } 15 \% \\
\text { related to } \\
\text { accident } \\
\text { rate, } 5 \% \\
\text { depend- } \\
\text { ing on } \\
\text { preventions } \\
\text { activities }\end{array}$ & $\begin{array}{l}10 \% \\
\text { surcharge } \\
\text { from } 2009, \\
\text { if enterprise } \\
\text { has not } \\
\text { received any } \\
\text { bonus for } 5 \\
\text { consecutive } \\
\text { years }\end{array}$ & $\begin{array}{l}\text { Method: before-after testing, } \\
\text { matched natural control group; } \\
\text { accident rates of participating enter- } \\
\text { prises are much lower than average } \\
\text { for sector; incentivized enterprises } \\
\text { had, on average, } 28 \% \text { less accidents } \\
\text { after } 6 \text { years, whereas the other } \\
\text { companies in the sector had only } \\
16 \% \text { reduction in accidents }\end{array}$ & $\begin{array}{l}\text { Butchery } \\
\text { sector, } \\
\text { SME-friendly }\end{array}$ \\
\hline $\begin{array}{l}\text { Belgian federal } \\
\text { public service } \\
\text { employment, labor } \\
\text { and social dialogue }\end{array}$ & $\begin{array}{l}\text { Experience rating } \\
\text { depending on accident } \\
\text { rates }\end{array}$ & .. & $\begin{array}{l}\leq 15 \% \\
\text { rebate on } \\
\text { insurance } \\
\text { premium }\end{array}$ & $\begin{array}{l}\leq 30 \% \text { sur- } \\
\text { charge on } \\
\text { insurance } \\
\text { premium }\end{array}$ & $\begin{array}{l}\text { Not available - program started } \\
\text { only in } 2009\end{array}$ & .. \\
\hline
\end{tabular}

MATA insurance; Farmers' Workers'

Compensation

Insurance, Finland

Italian Workers Compensation Authority (INAIL)

General Health Insurance (AOK) of Lower Saxony, Germany

Work accident insurance, Poland
Experience rating premium discount program in the farming sector, depending on accident rates

Experience rating depending on accident rates and reduction of compulsory insurance premium following prevention support measures adopted by companies

Enterprise for health: promoting health management among companies in Lower Saxony, setup of health management system and certification

Experience rating depending on number of work accidents, occupational diseases and number of workers exposed to harmful working conditions at workplace. The insurance premium differs in relation to a branch and company size
$€ 217.00$ (related to $\leq 50 \%$ average income); rebate on $€ 42.92$ base fee + insurance $1.3 \%$ of income; premium $€ 53.94$ average (estimate); $\leq € 87.07$ maximum ..

$€ 5115.00(15 \%$

of average in-

come); €426 per

worker per year for

incentives

$€ 176.71(1.67 \%$ of $\leq 50 \%$ average income) rebate on

insurance

premium complirebate on annual insurance remium
None

Method: Interrupted time series analysis; monitoring of accident rates/injury claims; since the introduction of premium rebates, the accident rate has fallen by $\geq 10 \%$

\section{$22-35 \%$} surcharge on acci- on insurance companies that succeeded in

Method: before-after testing; evaluation of the number of dent rate, premium obtaining a premium discount ances and entions

8.33\% None premium
Method: before-after testing, matched natural control group; monitoring of the number of premium discounts; participating enterprises had a reduction in sick

$\leq 50 \%$ surcharge on insurance leave by $6.7 \%$, in sick pay by $7.6 \%$
Method: before-after testing; risk category is based on 3-year data provided by premium payers to Social Insurance Fund. This is the basis to set a correcting index, which is the result of a comparison of the individual company risk and the risk of the sector.
Agriculture sector/ SME-friendly

SME friendly

$$
\begin{aligned}
& \text { Individual } \\
& \text { company, } \\
& \text { SME possible } \\
& \\
& \text { Individual } \\
& \text { premium } \\
& \text { variation } \\
& \text { applies only } \\
& \text { for compa- } \\
& \text { nies with } \\
& \geq 10 \text { insured } \\
& \text { workers }
\end{aligned}
$$


Table 2. Subsidy-related incentive schemes. [SME=small- and medium-sized enterprise]

\begin{tabular}{|c|c|c|c|c|c|c|c|}
\hline Organization & Purpose & $\begin{array}{l}\text { Type of } \\
\text { incentive }\end{array}$ & Budget & Beneficiaries & $\begin{array}{l}\text { Ratio per } \\
\text { person }\end{array}$ & Evaluation & Target group \\
\hline $\begin{array}{l}\text { Polish Agency } \\
\text { for Enterprise } \\
\text { Development } \\
\text { (governmental), } \\
\text { EU PHARE } \\
\text { programme }\end{array}$ & $\begin{array}{l}\text { Supporting SMEs } \\
\text { in OSH manage- } \\
\text { ment through } \\
\text { capacity-building } \\
\text { and preventive } \\
\text { culture }\end{array}$ & Subsidy & $€ 7.7$ million & $\begin{array}{l}\text { Training for } 160 \\
\text { OSH consultants, } \\
50 \text { representa- } \\
\text { tives of chambers } \\
\text { of commerce, } \\
400 \text { employers } \\
\text { and } 800 \text { SME } \\
\text { employees }\end{array}$ & $\begin{array}{l}€ 5461 \\
\text { per } \\
\text { person } \\
\text { (1410) } \\
\text { involved }\end{array}$ & $\begin{array}{l}\text { Project has been success- } \\
\text { fully managed; good collabora- } \\
\text { tion with partners from trade } \\
\text { organizations }\end{array}$ & SME focus \\
\hline $\begin{array}{l}\text { Central Institute for } \\
\text { Labour Protection, } \\
\text { National Labour } \\
\text { Inspectorate } \\
\text { (governmental), } \\
\text { Poland }\end{array}$ & $\begin{array}{l}\text { Promoting a } \\
\text { systematic } \\
\text { approach to OSH } \\
\text { management in } \\
\text { Polish enterprises }\end{array}$ & $\begin{array}{l}\text { Indirect } \\
\text { subsidy }\end{array}$ & .. & $\begin{array}{l}92 \text { enterprises } \\
\text { have participated } \\
\text { in the programme }\end{array}$ & .. & $\begin{array}{l}\text { Method: before-after testing, } \\
\text { matched natural control group; } \\
70 \% \text { of companies have fewer } \\
\text { accidents since introduction of } \\
\text { OSH management system; } 50 \% \\
\text { report fewer workers in hazard- } \\
\text { ous conditions; } 70 \% \text { have seen } \\
\text { insurance premiums fall }\end{array}$ & $\begin{array}{l}\text { Individual } \\
\text { companies, } \\
\text { SME-friendly }\end{array}$ \\
\hline $\begin{array}{l}\text { Allgemeine Unfall- } \\
\text { versicherungs- } \\
\text { anstalt, (AUVA), } \\
\text { Austrian accident } \\
\text { insurance }\end{array}$ & $\begin{array}{l}\text { Consultancy for } \\
\text { safety and health } \\
\text { management for } \\
\text { Austrian SMEs }\end{array}$ & $\begin{array}{l}\text { Low-cost } \\
\text { consul- } \\
\text { tancy }\end{array}$ & .. & .. & .. & $\begin{array}{l}\text { Since the project started in } 2006 \text {, } \\
\text { the participation rate is growing }\end{array}$ & $\begin{array}{l}\text { Individual } \\
\text { companies, } \\
\text { SME-friendly }\end{array}$ \\
\hline $\begin{array}{l}\text { Forebyggelses- } \\
\text { fonden (Prevention } \\
\text { Fund), Denmark } \\
\text { (governmental) }\end{array}$ & $\begin{array}{l}\text { Prevent the } \\
\text { early retirement of } \\
\text { workers }\end{array}$ & Subsidy & $\begin{array}{l}€ 27 \text { million in } \\
2007 ; € 47 \\
\text { million per year } \\
\text { from } 2008 ; \\
€ 403 \text { million in } \\
10 \text { years }\end{array}$ & $\begin{array}{l}82 \text { projects have } \\
\text { been supported } \\
\text { so far }\end{array}$ & $\begin{array}{l}€ 330000 \\
\text { per } \\
\text { project }\end{array}$ & $\begin{array}{l}\text { Monitoring of applications and } \\
\text { approved projects; management } \\
\text { of projects with low administra- } \\
\text { tive burden }\end{array}$ & $\begin{array}{l}\text { Sectors, voca- } \\
\text { tional groups, } \\
\text { companies, } \\
\text { SME-friendly }\end{array}$ \\
\hline $\begin{array}{l}\text { Italian Workers' } \\
\text { Compensation } \\
\text { Authority (INAIL) } \\
\text { (governmental) }\end{array}$ & $\begin{array}{l}\text { Business financing } \\
\text { for programs and } \\
\text { projects in compli- } \\
\text { ance with OSH } \\
\text { requirements, OSH } \\
\text { management }\end{array}$ & $\begin{array}{l}\text { Sub- } \\
\text { sidized } \\
\text { bank } \\
\text { credit } \\
\text { with } \\
\text { lower } \\
\text { interest } \\
\text { rate }\end{array}$ & $\begin{array}{l}€ 170 \text { million } \\
\text { subsidies in } \\
2009 \text {, leading } \\
\text { to } € 700 \text { million } \\
\text { investment }\end{array}$ & 133000 workers & $\begin{array}{l}€ 1278 \\
\text { per } \\
\text { worker }\end{array}$ & $\begin{array}{l}\text { Method: before-after testing, } \\
\text { matched natural control group; } \\
\text { statistical analysis of the effec- } \\
\text { tiveness of prevention actions; } \\
\text { participating companies have } \\
13-25 \% \text { fewer accidents than } \\
\text { average }\end{array}$ & $\begin{array}{l}\text { Sectors, groups } \\
\text { of companies, } \\
\text { SME-friendly }\end{array}$ \\
\hline $\begin{array}{l}\text { Professional } \\
\text { Experience Fund; } \\
\text { Belgian federal } \\
\text { public service } \\
\text { employment, labor } \\
\text { and social dialogue } \\
\text { (governmental) }\end{array}$ & $\begin{array}{l}\text { Prevent early } \\
\text { retirement by sub- } \\
\text { sidizing projects } \\
\text { of employers that } \\
\text { improve working } \\
\text { organization and } \\
\text { conditions of older } \\
\text { workers. }\end{array}$ & Subsidy & $\begin{array}{l}€ 4.2 \text { million } \\
\text { per year }\end{array}$ & $\begin{array}{l}\text { About } 300 \\
\text { projects with } \\
12000 \text { work- } \\
\text { ers in } 2009 . \text { In } \\
\text { total } 5 \text { sectorial } \\
\text { contracts }\end{array}$ & $\begin{array}{l}€ 14000 \\
\text { per } \\
\text { project/ } \\
\text { year; } \\
€ 350 \text { per } \\
\text { worker/ } \\
\text { year }\end{array}$ & $\begin{array}{l}\text { Method: before-after testing; } \\
\text { yearly evaluation of results; } \\
\text { monitoring of the types of work- } \\
\text { place adaptations applied for }\end{array}$ & $\begin{array}{l}\text { Sectors, } \\
\text { companies }\end{array}$ \\
\hline $\begin{array}{l}\text { Ministry of } \\
\text { Social Affairs and } \\
\text { Employment, } \\
\text { Ministry of Finance } \\
\text { (governmental), } \\
\text { the Netherlands - } \\
\text { farbo scheme }\end{array}$ & $\begin{array}{l}\text { Subsidies for } \\
\text { innovative and } \\
\text { ergonomic equip- } \\
\text { ment for improve- } \\
\text { ment of working } \\
\text { conditions }\end{array}$ & Subsidy & $\begin{array}{l}€ 4.5 \text { million in } \\
2005\end{array}$ & $\begin{array}{l}1325 \text { organiza- } \\
\text { tions in } 2005\end{array}$ & $\begin{array}{l}€ 3400 \\
\text { per } \\
\text { organiza- } \\
\text { tion }\end{array}$ & $\begin{array}{l}\text { Method: before-after testing; } \\
\text { assessments of the number of } \\
\text { applications/ allocations/ } \\
\text { purchased tools; the efficiency of } \\
\text { the scheme; effects on working } \\
\text { conditions: } 76 \% \text { of employ- } \\
\text { ers said that new equipments is } \\
\text { beneficial for working conditions, } \\
57 \% \text { said that health complaints } \\
\text { have been reduced }\end{array}$ & Companies \\
\hline $\begin{array}{l}\text { Ministry of } \\
\text { Social Affairs and } \\
\text { Employment, } \\
\text { Ministry of Finance } \\
\text { (government and } \\
\text { social partners), } \\
\text { the Netherlands - } \\
\text { convenant program }\end{array}$ & $\begin{array}{l}\text { Subsidies for } \\
\text { OSH programs } \\
\text { organized by social } \\
\text { partners }\end{array}$ & Subsidy & $\begin{array}{l}€ 303 \text { million - } \\
55 \% \text { from } \\
\text { sectors and } \\
45 \% \text { from } \\
\text { government }\end{array}$ & $\begin{array}{l}4.37 \text { million work- } \\
\text { ers ( } 52 \% \text { of all } \\
\text { Dutch workers) }\end{array}$ & $\begin{array}{l}€ 14.44 \\
\text { aver- } \\
\text { age per } \\
\text { worker } \\
\text { (€10-30 } \\
\text { range) }\end{array}$ & $\begin{array}{l}\text { Method: before-after testing, } \\
\text { natural control group; reduced } \\
\text { sick leave, equivalent to a } 2.7 \\
\text { billion benefits compared to } \\
\text { non-covenant sectors; but not } \\
\text { better health outcomes; creation } \\
\text { of OSH infrastructure to improve } \\
\text { long-term working conditions }\end{array}$ & Companies \\
\hline
\end{tabular}


Table 3. Cost-benefit calculations of three incentive schemes.

\begin{tabular}{|c|c|c|c|c|c|c|c|}
\hline Organization & $\begin{array}{l}\text { Number of } \\
\text { workers and } \\
\text { enterprises }\end{array}$ & $\begin{array}{l}\text { Costs of } \\
\text { incentive } \\
\text { system }\end{array}$ & $\begin{array}{l}\text { Annual incentive } \\
\text { per worker }\end{array}$ & $\begin{array}{l}\text { Contributions } \\
\text { to the } \\
\text { incentive } \\
\text { scheme }\end{array}$ & $\begin{array}{l}\text { Positive intervention } \\
\text { consequences }\end{array}$ & $\begin{array}{l}\text { Benefit of incentive } \\
\text { system }\end{array}$ & $\begin{array}{l}\text { Payout } \\
\text { ratio } \\
\text { per } € 1 \\
\text { invested }\end{array}$ \\
\hline $\begin{array}{l}\text { Fleischerei } \\
\text { Berufsgenossenschaft } \\
\text { (FBG), German social } \\
\text { accident Insurance } \\
\text { Institution for the meat- } \\
\text { processing industry }\end{array}$ & $\begin{array}{l}255000 \\
\text { workers } \\
(2008) ; \\
20000 \\
\text { enterprises } \\
(2008)\end{array}$ & $\begin{array}{l}€ 8.32 \\
\text { million } \\
\text { (6 years, } \\
2002- \\
2007)\end{array}$ & $\begin{array}{l}\leq € 14.06 \text { for } \\
\text { average income } \\
\text { ( } 5 \% \text { of pre- } \\
\text { mium); } € 5.5 \text { per } \\
\text { worker annually }\end{array}$ & $\begin{array}{l}€ 292.12 \\
\text { (annual in- } \\
\text { surance pre- } \\
\text { mium related } \\
\text { to average } \\
\text { income) }\end{array}$ & $\begin{array}{l}\text { Approximately } 6000 \text { accidents } \\
\text { prevented over } 6 \text { years, about } \\
1000 \text { accidents per year on } \\
\text { average }\end{array}$ & $\begin{array}{l}6000 \times € 6670= \\
€ 40.02 \text { million } \\
\text { total } € 40.02 \text { million }\end{array}$ & $€ 4.81$ \\
\hline $\begin{array}{l}\text { MATA Insurance; premium } \\
\text { discount programme in } \\
\text { the Farmers' Workers' } \\
\text { Compensation Insurance, } \\
\text { Finland }\end{array}$ & $\begin{array}{l}110000 \\
\text { self-em- } \\
\text { ployed } \\
\text { farmers } \\
(2003)\end{array}$ & $\begin{array}{l}€ 35.6 \\
\text { million } \\
\text { (6 years, } \\
1998- \\
2003, \\
\text { estimate) }\end{array}$ & $\begin{array}{l}€ 53.94 \text { aver- } \\
\text { age (estimate) } \\
\leq € 87.07\end{array}$ & $\begin{array}{l}€ 217 \text { (related } \\
\text { to average } \\
\text { income); } \\
€ 42.92 \text { base } \\
\text { fee }+1.3 \% \text { of } \\
\text { income }\end{array}$ & $\begin{array}{l}5014 \text { accidents prevented } \\
\text { over } 6 \text { years }\end{array}$ & $\begin{array}{l}873 x € 403= \\
€ 0.35 \text { million; } 3936 \\
\times € 6670=€ 26.3 \\
\text { million }+205 \times \\
€ 46000=€ 9.43 \\
\text { million; total } \\
€ 36.08 \text { million }\end{array}$ & $€ 1.01$ \\
\hline $\begin{array}{l}\text { Ministry of Social Affairs } \\
\text { and Employment, Ministry } \\
\text { of Finance (government } \\
\text { and social partners), the } \\
\text { Netherlands - convenant } \\
\text { program }\end{array}$ & $\begin{array}{l}4.37 \text { million } \\
\text { workers } \\
52 \% \text { of } \\
\text { all Dutch } \\
\text { workers }\end{array}$ & $\begin{array}{l}€ 303 \\
\text { million } \\
\text { total (8 } \\
\text { years } \\
1999- \\
2007)\end{array}$ & $\begin{array}{l}€ 14.44 \text { average } \\
\text { per worker over } \\
8 \text { years (range } \\
€ 10-30 \text { ); €3.61 } \\
\text { per worker per } \\
\text { year for } 4 \text {-year } \\
\text { covenant }\end{array}$ & $\begin{array}{l}55 \% \text { from } \\
\text { sectors; } \\
45 \% \text { from } \\
\text { government }\end{array}$ & $\begin{array}{l}\text { Sick leave of participating sec- } \\
\text { tors decreased more than other } \\
\text { sectors; participating sectors } \\
\text { had on average } 28 \% \text { less sick } \\
\text { leave after } 6 \text { years, whereas } \\
\text { non-participating sectors had } \\
\text { only } 11 \% \text { sick leave reduction }\end{array}$ & $\begin{array}{l}€ 2.7 \text { billion due to } \\
\text { reduced sick leave, } \\
\text { compared to non- } \\
\text { covenant sectors }\end{array}$ & $€ 3.00$ \\
\hline
\end{tabular}

the 14 cases described above met these criteria (see table 3): the insurance incentive schemes in the German butchery (12) and Finnish agricultural sectors (13) as well as the subsidy case of the Dutch covenant program (14). For the two insurance schemes, we calculated the cost-benefit analysis using the data provided in the case studies. The description of the Dutch covenant program already included a cost-benefit analysis; we only calculated the cost per worker per year.

From the German butchery sector [Fleischerei Berufsgenossenschaft (FBG)], we have exact numbers of the costs of the incentives for each year between 2002-2007. For our analysis, we added all the costs from 2002, when the incentive program started, until 2007 ( $€ 8.32$ million, see table 3 ). When we calculated the annual cost of the incentive per worker for all 255000 workers insured, the result was $€ 5.5$ per worker per year. This amount relates to all workers in the sample including those whose enterprises did not participate in the incentive scheme. When we calculated the actual bonus for those workers whose enterprise was successfully taking part in the program, the possible incentive was $€ 14.06$ (ie, the potential gain per worker through the reduction of the premium). Depending on the size of the company, this incentive can render OSH prevention attractive for an enterprise.

We calculated the cost for the incentive scheme of the Finnish agricultural sector [Maatalousyrittäjän tapaturmavakuutus (MATA)] using the information provided in Rautiainen et al (13). Taking the yearly insurance contributions and the given rate of $93 \%$ accident-free farmers per year, we calculated the yearly premium discounts from the introduction of the system in 1998 until 2003.
It is clear from the design of the incentive system, which offers a rebate of $\leq 50 \%$ on the wage-related part of the insurance premium, that the costs of the system are much higher than that of FBG. The maximum premium reduction could be $€ 87.07$ per farmer per year versus $€ 14.06$ (table 3), but also the calculated average cost of $€ 53.94$ is relatively high compared to both FBG $(€ 5.50)$ and the Dutch covenant program. The latter had the highest budget in total but was related to the most workers as well, resulting in costs of $€ 14.44$ per worker accumulated over eight years (1999-2007). It must be clarified that the sectoral agreements under the Dutch convenant program lasted only about four years per sector and, therefore, the annual budget per worker was about $€ 3$.61. Subsequently, the actual amount of money spent per worker was relatively low compared to the FBG and MATA schemes.

In order to complete a cost-benefit analysis in addition to the costs of the incentive schemes, the economic benefits have to be calculated. In the Dutch covenant case study, the benefit data was provided in terms of prevented sick leave compared to other sectors. For the German and Finnish insurance cases, the benefit was calculated based on accidents prevented as a result of the incentive scheme. For this purpose, we used appraisal values of the UK Health and Safety Executive (HSE) as these aim to "give the unit costs to society for workplace accidents and ill health". The values were created "to estimate the benefits of proposed measures, which aim to improve occupational health and safety, and to compare such benefits with the cost of government intervention" (15). The values also differentiate accidents according to their severity [ie, $€ 403$ for a minor 
injury, $€ 6670$ for a reportable injury causing $>3$-day absence, $€ 46000$ for a major injury with $>3$-month absence (ratio $£ 1=€ 1.15$ on $09 / 02 / 2010$, see table 3].

In the MATA scheme, the exact distribution of several accident severity groups was available. FBG provided only accident numbers for $>3$-day absence, which leads to the assumption that the economic benefit of the incentive scheme is probably underestimated as major injuries are calculated at the same cost as all reportable accidents. The overall benefit of both schemes was then calculated by multiplying the number of prevented accidents by the HSE appraisal value according to the respective accident severity level.

\section{Results}

\section{Case study review}

\section{Effectiveness and benefits of economic incentive schemes.}

The review of the 14 case studies shows that economic incentives can be effective in a great variety of settings in order to promote OSH in enterprises. Of the 14 investigated incentive schemes, 13 had undergone some kind of quantitative or qualitative evaluation. Most qualitative evaluations related to the successful management of the program, the participation rate of companies or workers, and the effectiveness of the promoted measures in the workplace. In seven case studies, we found quantitative indicators for positive effects on the working conditions for the participating companies (see also tables 1 and 2): (i) FBG-participating enterprises have had about $28 \%$ less reportable accidents since the introduction of the incentive scheme in 2001, compared to an average sectoral reduction of only $16 \%$ during the same period. In total numbers, this means about 1000 accidents less per year in incentivized companies (10); (ii) in MATA-subscribed enterprises, the accident rate dropped by $10.2 \%$, preventing over 5000 accidents since the introduction of the incentive scheme (13); (iii) AOK, the German health insurance firm, found that sick pay and absenteeism decreased by $7.6 \%$ and $6.7 \%$, respectively, among member enterprises introducing a modern health management system (11); (iv) of the Polish enterprises who introduced an OSH management system, supported by the Central Institute for Labor Protection (CIOP), 70\% had less accidents and lower insurance premiums and $50 \%$ had less workers operating in hazardous conditions (11); (v) the Italian Workers' Compensation Authority (INAIL) subsidies bank credits to stimulate OSH investments in small- and medium-sized firms, which show $13-25 \%$ less accidents than comparable enterprises (11); (vi) the Dutch subsidy program for investments in new OSH-friendly machinery and equipment (farbo scheme) led to better working conditions in $76 \%$ of participating enterprises ( $40 \%$ of employers said that new equipment was highly beneficial, 36\% reasonably found it to be beneficial) (11); (vii) the Dutch covenant program reduced sick leave in participating sectors by $28 \%$ whereas other sectors had only an $11 \%$ reduction in sick leave (14).

Size of the incentive for enterprises. Among the insurancebased incentive schemes, the size of the incentive is usually indicated as a percentage of the insurance premium, which can either reduce (bonus) or increase the premium (malus). Whereas all six insurance schemes in this review had the possibility of a bonus, four also contained provisions for a malus. The bonus varied between $5-50 \%$. The largest spread was found in the relatively new Polish insurance incentive system, where the premiums can vary between $50 \%$ bonus and $50 \%$ malus, but no evaluation of this system has been done so far. The Finnish farming sector case delivered a remarkable $10.2 \%$ reduction in accidents with a bonus of $50 \%$ premium reduction based on experience rating. The FGB example achieved significant accident reduction by incentivizing specific prevention measures through an $\leq 5 \%$ reduction in premiums.

When we consider the absolute magnitude of an insurance-based incentive, the type of insurance may play a crucial role. Of the six incentives under review, five are based on classical "work accident insurance". The AOK case from Germany works within the framework of an overall health insurance. As health insurance premiums are usually much higher than accident insurance premiums (eg, around 15\% of salary in Germany), an incentive for this type of insurance could have much greater impact on corporate decisions with respect to the promotion of OSH. Even if the percentage of the incentive is only $8.33 \%$ of the yearly insurance premium, this amounts to $€ 426$ of maximum yearly incentive in insurance premium reduction (see tables 1 and 3, FBG $€ 14.06$, MATA $€ 87.07)$.

Among the subsidy incentive schemes, the absolute magnitude of incentives also varied extensively. In the course of this study, we were able to calculate the incentive ratio per person or organization for six of the eight cases. The subsidies ranged from $€ 3.61$ per worker in the Dutch covenant system, to $€ 5461$ per person (experts, workers, and employers) in the Polish program for enterprise development. The latter consisted of a comprehensive service package, including training, developments of guidelines, and grants for safety equipment.

\section{Cost-benefit analysis on a societal level}

Only three incentive schemes were suitable for deeper cost-benefit calculations (table 3). These were the insurance incentive schemes of the FBG (12) and MATA (13) and, from the subsidy cases, only the Dutch covenant 
program (14). Nevertheless, these three incentive programs cover large samples of workers in their respective countries: 250000 in Germany, 110000 in Finland, and 4.37 million workers in the Netherlands or $52 \%$ of Dutch workers. Subsequently, even if the number of cases was small, the scope of the incentive schemes was large.

\section{Effectiveness in preventing accidents and sick leave. The} effectiveness of both insurance-based schemes was measured by the overall reduction of accidents, considering the years mentioned in table 3 . In the MATA case, an interrupted time series analysis was conducted in order to measure the effect of the incentive scheme. As a result, there was a statistically significant reduction of 5014 $(10.2 \%)$ accidents calculated at the 5\% significance level (13). For FGB, a controlled before-after testing design was used to determine the effect. The participating enterprises ( $46 \%$ of all insured companies) had, on average, 1000 accidents less per year than non-participating enterprises. Incentivized enterprises had on average $28 \%$ fewer accidents after 6 years, whereas the other companies in the sector had only $16 \%$ accident reduction.

The Dutch evaluation (14) used sick leave as an outcome indicator, comparing covenant sector participants with non-participating sectors. Sick leave of covenant sectors decreased much more than in other areas of the economy. Participating sectors had on average $28 \%$ less sick leave after six years, whereas the other sectors had only $11 \%$ sick leave reduction.

Cost-benefit calculations. The cost-benefit analysis was carried out by calculating the ratio between the costs of the incentive scheme and the benefits from prevented accidents and sick leave as described in the methodology section (table 3 , last column). For the FBG, a payout ratio of $€ 4.81$ could be calculated, whereas the MATA payout ratio of $€ 1.01$ delivered back only the invested incentives. Although the number of prevented accidents is quite impressive, the high rebates of $\leq 50 \%$ make the system quite expensive.

When presenting the Dutch case, Veerman (14) argued, however, not to attribute all $€ 2.7$ billion of the benefit due to reduced sick leave to the covenant program because sick leave is a complex phenomenon influenced by many factors (eg, motivational factors or the level of unemployment in a certain sector). However, as it was not possible to assess the net share of benefit attributable to the drop in sick leave, Veerman proposed to link $1 / 3$ of the sick leave reduction to the covenant program. This would result in the benefit being reduced to $€ 900$ million but still with a high payout ratio of $€ 3$ for every $€ 1$ invested. One could additionally argue that government's share of the investment was only $45 \%$, compared to the sectoral contribution of $55 \%$, which would deliver an even higher return on prevention for society.

\section{Discussion}

The review of 14 case studies showed that economic incentive schemes seem feasible in a variety of socioeconomic contexts. In general, not many case studies have been published in the scientific literature hitherto. Among the presented cases, only the study about the Finnish agricultural sector has been published in a peerreviewed scientific journal (13).

Therefore, the survey among the EU-OSHA network brought together a rich collection of information about European approaches to the provision of economic incentives that have been unknown in the scientific literature so far. However, the EU-OSHA collection may also yield methodological drawbacks: first, it may suffer from a publication bias. Second, member states may tend to inform EU-OSHA more about positive than negative examples.

\section{Effectiveness of incentives}

Out of the seven quantitative evaluations, five compared the improvements observed with other similar companies. That means, that in addition to the before-after testing, a kind of "natural" control group design was available, which is a good step towards establishing a valid evidence base, as many economic evaluation studies in OSH use only before-after comparisons (16). However, as none of the studies had a randomized control group, a selection bias cannot be excluded. It is possible that there is a systematic bias regarding $\mathrm{OSH}$ motivation due to the self-selection of participating companies.

The three studies included in the cost-benefit analysis delivered more details to underpin the effectiveness of the analyzed incentive schemes. Taking into consideration a possible selection bias (eg, FBG), accident figures were not the only outcome variables measured. Several other indicators - such as less cases of occupational skin diseases or commuting accidents - show the success of specific measures promoted by the incentive system. Also the high number of participating enterprises and the observation of the effect over a period of seven years (long-term effect) add to the plausibility of the effectiveness of the scheme (17). Further analysis showed that companies of all sizes took part in the incentive system and that there was no systematic variation regarding the criteria of company size.

The Dutch covenant program achieved an impressive reduction in sick leave in the covenant sectors, but this was not supported by a significant reduction in occupational risks and self-reported health complaints. Due to the participation of companies on voluntary basis, a selection bias cannot be excluded also in this 
case. However, the program was regarded as a success at national level, as it was able to mobilize many stakeholders to be more active in OSH. Many sectors cofinanced the program, employers were motivated, and an infrastructure for future improvements in $\mathrm{OSH}$ was created. Hopefully, the numerous efforts put into the program will have a long-term effect on health outcomes that will only be measurable at a future point in time.

In the Finnish agricultural sector case, there was no control group available, so an interrupted time series analyses was conducted that showed $10.2 \%$ less accidents following the intervention. In describing the achievement, the authors (13) discussed also if under-reporting could have contributed partly to the claim reduction, although actually no farmer would benefit economically from that practice. The maximum possible bonus in the insurance premium (ie, maximum $0.65 \%$ of annual income) would always be lower than the minimum lost time per diem compensation of $0.83 \%$ in case of an accident. Although under-reporting is discussed in the literature as a potential side-effect of experience rating schemes (18), the authors do not assume any substantial effect in this case because of the incentive design and further survey data, which does not support that under-reporting occurred.

\section{Limitations of cost-benefit calculations}

In our three cases, the outcome variables "prevented accidents" and "sick leave" were used to calculate the benefits of the both insurance schemes from FBG and MATA. We have used the HSE's (15) standardized costs of accidents, since the appraisal value is an approach to calculate the costs to society. They consist of human costs (pain, grief, and suffering), costs of lost output (wages and sick pay), and resource costs (administration, recruitment, and medical treatment). Although the HSE has excellent credibility, further research is needed to investigate the transferability of the appraisal values to other industrialized countries, such as Germany and Finland. For the study at hand, we assumed these values to be reasonably transferable, but nevertheless the results should be interpreted with caution. We consider these appraisal values as quite conservative since the HSE assumes, regarding lost output, that "the firm does not suffer any decline in output as suitable arrangements to maintain output are made". However, experience shows that the socalled "opportunity cost" can be of a relatively high magnitude if, for example, contracts are lost due to interruptions in the production process. Furthermore, the HSE does not include any pension costs which may have to be paid for serious accidents and which are a considerable burden to society (16).

The major purpose of this review was to compare the costs and benefits of incentive schemes on a societal level in order to provide useful information to policy-makers. To this end, the use of the general HSE appraisals seems an adequate methodology with respect to data availability, time, and money. Further methodological drawbacks of our first approach are that the temporality of the underlying data with respect to national discount and inflation rates could not be accounted for as the exact yearly costs and benefits were not available for all three included incentive schemes. However, as we are comparing eurozone countries, we can assume that these temporality variables would not disturb the comparability of the schemes due to the stable and similar economic situation in those countries during the last decade.

\section{Implications for practice}

The cases provide valuable information for policy-makers about the range of possible interventions regarding economic incentives. More detailed descriptions of the cases can be found in the EU-OSHA report (12). Regarding cost-effectiveness, it can be concluded from the three more-detailed cost-benefit analyses that at least the costs of the incentives were offset at societal level by the number of prevented accidents and sick leave; in two cases, there was even a quite high payout ratio of $3: 1$ and $4.8: 1$.

The results of the cost-benefit analysis supports the assumption that incentive schemes stimulating specific prevention measures are probably more effective than the pure experience rating approach. As discussed in the introduction, this should be especially valid for smalland medium-sized companies that often does not profit from experience ratings.

In the end, the question of offering economic incentives to improve OSH often remains a political one. Of course, different social, economic, and political framework conditions have to be taken into account in each country (18). Economic incentives should be only offered for prevention activities that go beyond minimum legal requirements. Policy-makers will have to decide about the optimal mix of policy initiatives to promote OSH. Public resources could also be spent on information campaigns, OSH research, and an increased number of labor inspectors. Studies like this review can contribute to the question of optimal public resources allocation by providing information about the effectiveness and efficiency of different incentives scheme options.

Besides the objective to motivate enterprises to improve their OSH performance, experience rating and other economic incentives have been introduced in many countries because it is perceived as a question of justice. According to the "user-pays principle" those enterprises that cause more costs to the community should also contribute more. Economic incentives have frequently been introduced for ethical reasons in order to reward 
corporate good moral behavior. From this perspective, the added motivational effect for improving OSH performance is a desired, but surely not the only, reason for introducing an incentive.

\section{Implications for research}

In conclusion, we argue that more and better evaluation of economic incentive schemes is needed in order to know which kind of incentives would be most effective under which circumstances. This is in line with recent scientific literature on the economic evaluation of OSH interventions (19). Generally, evaluation studies about economic incentives have to take place in a natural setting which implies that it is never possible to exclude all potential side effects. The best way to control weaknesses of the presented case studies, such as a possible selection bias, would be to carry out randomized controlled trials.

However, insurance firms and other incentive-offering organizations have been reluctant so far to offer an incentive randomly to its clients for research reasons. Besides the political and, in competitive market systems, potential economic problems faced by the organization, there are also ethical concerns. If such incentive schemes reduce accidents and employee ill-health in a high share of participating enterprises, as shown in several of the case studies we examined, it can be argued that every enterprise should equally have the possibility to protect the health of its workers. Nevertheless incentive-offering organizations should have an interest in finding out the effectiveness of their incentive schemes. A possible solution to political and ethical concerns could be the randomized introduction of incentives with a time delay between different groups. Using such a method, all companies could benefit from the incentive in the end but start the scheme at different points in time.

Even if a "gold-standard" evaluation cannot be realized, a lot can be done to improve current reporting, which should be consistent in using the same evaluation criteria. Therefore a better cooperation between researchers and incentive-offering organizations would be useful, such as for instance the interdisciplinary expert group of EU-OSHA on economic incentives.

\section{Acknowledgements}

This article is based on an EU-OSHA project about economic incentive schemes in Europe. Therefore we would like to thank the economic incentives expert group and all European partners as well as the EU-OSHA and topic centre working environment staff who contributed to project.

\section{References}

1. European Commission. Improving quality and productivity at work: community strategy 2007-2012 on health and safety at work. Brussels: European Commission; $\operatorname{COM}(2007) 62$ final [cited 17 May 2010]. Available from http://eur-lex.europa.eu/ LexUriServ/LexUriServ.do?uri=COM:2007:0062:FIN:en:PDF.

2. Tompa E, Trevithick S, McLeod C. A systematic review of the prevention incentives of insurance and regulatory mechanisms for occupational health and safety. Scand J Work Environ Health. 2007;33(2):85-95.

3. Durbin D, Butler RJ. Prevention of disability from workrelated sources: the roles of risk management, government intervention, and insurance. In: Thomason T, Burton JF, Hyatt DE, editors. New approaches to disability in the workplace, Industrial relations research association series. Madison (USA): University of Wisconsin-Madison; 1998. p 63-86.

4. Thomason T. Economic incentives and workplace safety. In: Sullivan F, editor. Preventing and managing disabling injury at work. London (UK): Taylor and Francis Incorporated; 2003. p 183-202.

5. Sozialgesetzbuch Siebtes Buch - Gesetzliche Unfallversicherung [Seventh Book of German Social Law Statury accident insurance], §162 SGB VII (July 23, 2004).

6. Kötz H, Schäfer HB. Schadensverhütung durch ökonomische Anreize: eine empirische Untersuchung [Prevention of harm through economic incentives: an empirical study]. Arch Civilistische Prax. 1989;189:502-25.

7. Schulz U. Risikogerechte Finanzierung als Gestaltungsfaktor in der Prävention der gewerblichen Berufsgenossenschaften [Risk-adequate pricing as design factor in statutory accident insurances]. Die BG. 1996;2:144-8.

8. Schulz U. Bonus-Malus-Systeme der gewerblichen Berufsgenossenschaften [Bonus-malus systems of statutory accident insurances]. Sankt Augustin (Germany): Hauptverband der Gewerblichen Berufsgenossenschaften [Umbrella organisation of German statutory accident insurances]; 1999.

9. Clinch JP, Convery FJ, Fitzgerald E, Rooney SM. Economic instruments for sustainable development: improving the external and working environments. Luxembourg: Office for Official Publications of the European Communities; 2000.

10. Elsler D. European comparison of economic incentives in occupational safety and health. In: Berlin C, Bligård L-O, editors. Proceedings of the 39th Nordic Ergonomics Society Conference; 1-3 October 2007; Lysekil, Sweden. Gothenburg (Sweden); Chalmers University of Technology; 2007.

11. Elsler D, Taylor TN, editors. Economic incentives to improve occupational safety and health: a review from the European perspective. Luxembourg: Publications Office of the European Union; 2010. In press.

12. Van den Broek K, Krüger H. E-Facts 50: Cost-benefit-analysis of economic incentives at national level. Bilbao: European Agency for Safety and Health at Work; 2010. In press. 
13. Rautiainen RH, Ledolter J, Sprince NL, Donham KJ, Burmeister LF, Ohsfeldt R, Reynolds SJ, et al. Effects of premium discount on workers' compensation claims in agriculture in Finland. Am J Ind Med. 2005;48(2):100-9.

14. Veerman TJ. Subsidies for safe and healthy workplaces: sectoral covenants in the Netherlands, 1999-2007. Presented at EU-OSHA / Ecosh workshop on economic incentives; 16 November 2009; Bilbao. Cited 10 February 2010.

15. Health and Safety Executive (HSE). Economic Analysis Unit (EAU) Appraisal values 2008 [Internet]. United Kingdom: HSE; 2008 [cited 17 May 2010]. Available from: http://www. hse.gov.uk/economics/eauappraisal.htm

16. Verbeek J, Pulliainen M, Kankaanpää E. A systematic review of occupational safety and health business cases. Scand J Work Environ Health. 2009;35(6):403-12.

17. Kohstall T, editor. Schlussbericht, Projekt "Qualität in der Prävention”, Teilprojekt: Wirksamkeit und Wirtschaftlichkeit finanzieller und nicht finanzieller Anreizsysteme, teil 2: Finanzielle Anreizsysteme [Final report, "Quality in prevention," Project: effectiveness and efficiency of financial and non-financial incentive systems, part 2: Financial incentive schemes] [Internet]. Berlin: Deutche Gesetzliche Unfallversicherung [German Social Accident Insurance]; 2006 [cited 10 February 2010]. Available from: http://dguv. $\mathrm{de} / \mathrm{iag} / \mathrm{de} /$ forschung/forschungsprojekte_archiv/qdp/qdp_ abschluss/_dokumente/qdp_ab14.pdf

18. Clayton A. The prevention of occupational injuries and illness: the role of economic incentives [Internet]. Melbourne: National Research Centre for OHS Regulation; 2002 [cited 10 February 2010 . Working paper 5. Available from: http://dspace.anu. edu.au/bitstream/1885/41128/2/working_paper_5.pdf

19. Elsler D, Nikov A. European approaches for economic incentives in occupational safety and health. In: Strasser H, Kluth K, Rausch H, Bubb H, editors. Quality of work and products in enterprises of the future. Stuttgart (Germany): Ergonomia Verlag; 2003.

20. Tompa E, Culyer AJ, Dolinschi R, editors. Economic evaluation of interventions for occupational health and safety. New York (NY): Oxford Press; 2008.

Received for publication: 4 February 2010 